\title{
ВПЛИВ КОМБІНАЦІЇ N-АЦЕТИЛГЛЮКОЗАМІНУ ТА КВЕРЦЕТИНУ В ІН'ЄКЦІЙНІЙ ФОРМІ НА ПЕРЕБІГ ІШЕМІЧНОЇ ГОСТРОЇ НИРКОВОЇ НЕДОСТАТНОСТІ В ЩУРІВ
}

Вступ. Оптимізація лікування гострої ниркової недостатності (ГНН) - важлива медико-фрармацевтична проблема. Гостра ниркова недостатність є поширеним ускладненням не тільки захворювань нирок, а й різних паліативних та оперативних методів лікування. В окремих групах хворих смертність від неї сягає 80 \%. Тому пошук ефективних засобів корекції ГНН є актуальним завданням сучасної експериментальної фрармакології. Перспективним підходом у вирішенні даної проблеми може стати впровадження фрармацевтичної комбінації на основі фрлавоноїду кверцетину та аміноцукру N-ацетилглюкозаміну в ін'єкційній формі.

Мета дослідження - провести експериментальне вивчення ефективності комбінації N-ацетилглюкозаміну та кверцетину в ін'єкційній фрормі за умов розвитку ішемічної гострої ниркової недостатності.

Методи дослідження. Дослідження виконували на моделі ішемічної ГНН у щурів, яку відтворювали шляхом тотальної оклюзії ниркових судин протягом 75 хв. Досліджувану комбінацію вивчали в дозі 30 мг/кг при щоденному внутрішньовенному введенні протягом 3-х діб порівняно з кверцетином (препарат "Корвітин"), який вводили внутрішньовенно у дозі 34 мг/кг. Ефективність препаратів оцінювали за загальним фрізичним станом тварин, видільною фрункцією нирок та показниками азотистого обміну.

Результати й обговорення. Під впливом досліджуваної комбінації в щурів з ГНН вірогідно $(p<0,05)$ відносно нелікованих тварин знижувалася летальність, спостерігали зменшення діурезу в 1,5 раза, протеїнурії у 2,4 раза, посилення клубочкової фрільтрації у 3,0 рази та канальчевої реабсорбції на 9,9 \%, підвищення сечової екскреції креатиніну в 1,4 раза і сечовини в 1,9 раза, що в цілому свідчило про нормалізацію фрункціонального стану нирок й азотистого обміну. Що стосується ефрективності, то комбінація при цьому вірогідно $(p<0,05)$ перевершувала дію корвітину за всіма дослідженими показниками.

Висновки. Комбінація N-ацетилглюкозаміну та кверцетину - ефективний засіб корекції гострої ниркової недостатності, який можна вводити внутрішньовенно. Доцільним є подальше вивчення цього препарату як засобу лікування ниркової патології.

КЛЮЧОВІ СЛОВА: N-ацетилглюкозамін; кверцетин; ін'єкційна форма; гостра ниркова недостатність.

ВСТУП. Ефективне лікування гострої ниркової недостатності (ГНН) - важлива проблема медико-фрармацевтичної практики сьогодення. Гостра ниркова недостатність $€$ поширеним ускладненням не тільки нефропатій, а й інших захворювань, а також може бути результатом проведення лікарської терапії і використання паліативних або оперативних методів лікування. Згідно зі статистичними даними, її поширеність становить 5-10 \% від усіх госпіталізованих пацієнтів [1]. Набагато частіше вона виникає у критичних хворих, досягаючи поширеності $67 \%$, при цьому в 5 \% розвивається тяжка ГНН, що потребує замісної ниркової терапії [2]. Протягом останніх 25 років відбулось майже 20-кратне збільшення захворюваності на ГНН, тому ця (с) С. К. Шебеко, І. А. Зупанець, Т. С. Сахарова, 2019. патологія набуває невпинного поширення [1]. Найбільшою небезпекою при ГНН є смертність, що знаходиться в межах до 15 \% у загальній популяції хворих і сягає 80 \% у пацієнтів, які перебувають у критичному стані [2]. Тому оптимізація лікування хворих та пошук ефективних несрропротекторних засобів $€$ актуальним завданням сучасної експериментальної фрармакології.

Перспективним підходом у вирішенні даної проблеми може стати впровадження комбінованих препаратів на основі мембранопротекторів та антиоксидантів природного походження, серед властивостей яких $€$ нефропротекторний вплив за різними механізмами дії. 3 огляду на це, науковий інтерес становить дослідження фрармацевтичної комбінації на основі фрлавоноїду 
кверцетину та аміноцукру $\mathrm{N}$-ацетилглюкозаміну (НАГ) в ін'єКційній формі.

Кверцетин є відомим орлавоноїдом рослинного походження, що володіє широким спектром фрармакологічних ефектів. Найбільш значимими серед них є антиоксидантний, антигіпоксичний, мембраностабілізувальний та протизапальний [3]. Завдяки цьому кверцетин має ангіопротекторні властивості й знижує проникність гломерулярних капілярів. Даний комплекс ефректів $€$ корисним у лікуванні ниркової патології. Ефективність кверцетину було підтверджено під час експериментальних досліджень на різних моделях нефропатій, у тому числі при ін'єкційному введенні [4].

$\mathrm{N}$-ацетилглюкозамін $є$ активним метаболітом глюкозаміну (ГА), несропротекторну дію якого було доведено раніше [5, 6]. Глюкозамін входить у складі глікозаміногліканів і глікопротеїнів до структур біологічних мембран, у тому числі до базальної мембрани нефронів, саме в ацетильованому вигляді, що й зумовлює його нефропротекторні властивості [7]. Тому потенційно НАГ у результаті прямого механізму дії має більш виражений нефропротекторний ефрект, ніж ГА.

3 огляду на особливості фрармакологічних властивостей кверцетину та НАГ, комбінований препарат на їх основі є перспективним для лікування ниркової патології, оскільки обидва компоненти взаємно доповнюють фрармакодинаміку один одного еоректами, необхідними для лікування захворювань нирок. У попередніх дослідженнях ми довели високу ефективність комбінацій кверцетину 3 похідними ГА при внутрішньошлунковому застосуванні в щурів на різних моделях нефропатій [4]. У зв'язку з цим, науковий інтерес становить дослідження комбінованого препарату в ін'єкційній формі, що може виявитись більш ефективним і бути корисним не тільки при латентному перебігу захворювань нирок, а й при ГНН та загостреннях хронічних несропатій.

Мета дослідження - провести експериментальне вивчення ефрективності комбінації N-ацетилглюкозаміну та кверцетину в ін'єкційній фрормі за умов розвитку ішемічної гострої ниркової недостатності.

МЕТОДИ ДОСЛІДЖЕННЯ. Експериментальне дослідження виконано на 38 білих нелінійних щурах масою 170-190 г, яких утримували на стандартному харчовому раціоні при вільному доступі до води, постійних вологості та температурному режимі [8]. Усі дослідження проводили відповідно до Директиви Ради ЄС 2010/63/EU про дотримання законів, постанов та адміністративних положень держав ЄС з питань захисту тварин, які використовуються для наукової мети [9].

Як об'єкт дослідження використовували комбінацію НАГ та кверцетину в ін'єкційній фрормі у співвідношенні 1:1. Для приготування комбінації застосовували НАГ у вигляді $6 \%$ розчину для ін'єкцій, який було розроблено та виготовлено як дослідну серію на ПАТ НВЦ “Борщагівський ХФЗ” (Україна). Кверцетин використовували у вигляді препарату "Корвітин" (ПАТ НВЦ “Борщагівський ХФЗ", Україна), що є ліофрілізованим порошком для ін'єкцій, який також окремо застосовували як референтний засіб.

У ході дослідження всіх тварин було поділено на такі групи: псевдооперований контроль $(\mathrm{n}=8)$; контрольна патологія $(\mathrm{n}=10)$; тварини 3 ГНН, які отримували внутрішньовенно комбінацію НАГ/корвітин у дозі 30 мг/кг (ЕД протекторною дією) $(\mathrm{n}=10) ;$ тварини з ГНН, які одержували внутрішньовенно корвітин у дозі 34 мг/кг (ЕД за за нефропротекторною дією [4]) $(n=10)$.

Для відтворення ішемічної ГНН у щурів під загальним наркозом (етамінал-натрій, 40 мг/кг, внутрішньочеревно) виконували серединну лапаротомію та викликали тотальну ішемію обох нирок протягом 75 хв за допомогою накладання мініатюрних судинних затискачів на ниркові ніжки [10]. Після видалення затискачів черевну порожнину пошарово ушивали. У тварин групи псевдооперованого контролю затискачів на ниркові ніжки не накладали. Усі маніпуляції проводили з дотриманням вимог асептики.

Починаючи з 1-го дня експерименту (за 1 год до відтворення ГНН) та протягом 3-х діб щури щоденно внутрішньовенно одержували відповідні тест-зразки у вигляді ін'єкційних розчинів. Тварини контрольних груп отримували внутрішньовенно еквівалентну дозу фрізіологічного розчину.

Через 48 год після початку реперфузії в щурів оцінювали фрункціональний стан нирок. У тварин визначали спонтанний добовий діурез за допомогою індивідуальних обмінних кліток. Далі їх виводили з досліду під загальною анестезією з метою отримання крові для біохімічних досліджень. У зібраній сечі визначали вміст протеїну пірогалоловим методом. У крові та сечі визначали вміст креатиніну за реакцією Яффе і сечовини за допомогою уреазного глутаматдегідрогеназного методу [11]. При цьому розраховували сечову екскрецію протеїну, креатиніну і сечовини. Швидкість клубочкової фрільтрації (ШКФ), канальцеву реабсорбцію (КР) та кліренс сечовини розраховували загальноприйнятими методами $[1,2,11]$. Усі біохімічні дослідження проводили за допомогою комерційних наборів "DiaSys" 
("DiaSys Diagnostic Systems GmbH", Німеччина) 3 використанням автоматичного біохімічного аналізатора "Express Plus" ("Bayer Diagnostics", Німеччина).

Результати обробляли методами описової статистики та представляли як середнє арисрметичне \pm стандартна помилка середнього (M $\pm \mathrm{m})$. Статистичний аналіз проводили методом однофракторного дисперсійного аналізу (ANOVA) 3 використанням критерію Тьюкі для апостеріорних порівнянь, а також за допомогою кутового перетворення Фішера при аналізі виживаності [12]. Обчислення виконували за допомогою програм IBM SPSS Statistics v. 22 (IBM Corp., США) та MS Excel 2016 (Microsoft Corp., США). Міжгрупові відмінності показників вважали статистично значущими при рівні вірогідності р<0,05.

РЕЗУЛЬТАТИ Й ОБГОВОРЕННЯ. РеЗУЛЬТаТИ дослідження показали, що після 75-хвилинної ішемії та наступної реперфрузії нирок у тварин групи контрольної патології на 3-тю добу експерименту формувалася виражена ГНН. Виживаність щурів при цьому становила 70 \% (табл. 1). У тварин спостерігали вірогідне відносно групи псевдооперованого контролю $(p<0,05)$ збільшення діурезу у 2,1 раза, зменшення ШКФ у 4,1 раза, а КР - на 10,2 \% (табл. 1). Окрім того, з'являлась протеїнурія, яка досягала 20,5 мг/добу (рис. 1).
Усе це свідчило про порушення видільної фуннції нирок та розвиток поліуричної срази ішемічної $\Gamma \mathrm{HH}$.

Внаслідок цього у тварин різко знижувалося виділення азотистих сполук та розгорталась азотемія. Вміст креатиніну та сечовини у крові, порівняно зі щурами групи псевдооперованого контролю, вірогідно $(\mathrm{p}<0,05)$ збільшився у 3,7 i 4,4 раза відповідно, а кліренс сечовини зменшився в 5,0 разів (табл. 2). Сечова екскреція при цьому також була вірогідно зниженою: креатиніну - на 12,0 \%, а сечовини - на 13,1 \% (рис. 2).

На відміну від цього, при застосуванні для лікування тварин дослідної комбінації НАГ/корвітин спостерігали виражену позитивну дію на перебіг ГНН. Під її впливом нормалізувався фрізичний стан щурів та зникала летальність. Відзначали вірогідне $(p<0,05)$ відносно нелікованих тварин покращення видільної фрункції нирок. При цьому діурез зменшувався в 1,5 раза, ШКФ збільшувалася у 3,0 рази, а показник КР зростав на 9,9 \% (табл. 1). Окрім того, комбінація сприяла вірогідному $(p<0,05)$ зниженню протеїнурії у 2,4 раза (рис. 1).

Під впливом комбінації НАГ/корвітин відбувались позитивні зміни і показників азотистого обміну. Комбінація вірогідно $(p<0,05)$ відносно групи контрольної патології посилювала сечову екскрецію креатиніну (в 1,4 раза) та сечовини (в

Таблиця 1 - Вплив комбінації N-ацетилглюкозаміну та корвітину

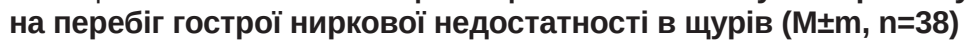

\begin{tabular}{|c|c|c|c|c|}
\hline Дослідна група & Виживаність, \% & Діурез, мл/добу & ШКФ, мл/добу & $\mathrm{KP}, \%$ \\
\hline Псевдооперований контроль & 100 & $5,4 \pm 0,2$ & $425,5 \pm 15,4$ & $98,73 \pm 0,04$ \\
\hline Контрольна патологія & $70^{\star}$ & $11,6 \pm 0,4^{*}$ & $103,0 \pm 5,2^{\star}$ & $88,68 \pm 0,38 *$ \\
\hline НАГ/корвітин, 30 мг/кг & $100^{\star * / \#}$ & $7,7 \pm 0,2^{\star / * \star / \#}$ & $307,0 \pm 11,3^{\star / * \star / / \#}$ & $97,46 \pm 0,11^{\star / * \star / \#}$ \\
\hline Корвітин, 34 мг/кг & $80^{*}$ & $8,7 \pm 0,3^{* / * *}$ & $194,8 \pm 8,8^{\star / * \star}$ & $95,51 \pm 0,18^{* / \star \star}$ \\
\hline
\end{tabular}

Примітки. Тут, у таблиці 2, на рисунках 1 і 2:

1. * - вірогідно відносно групи псевдооперованого контролю $(p<0,05)$.

2. ** - вірогідно відносно групи контрольної патології $(p<0,05)$.

3. \# - вірогідно відносно тварин, які отримували корвітин $(p<0,05)$.

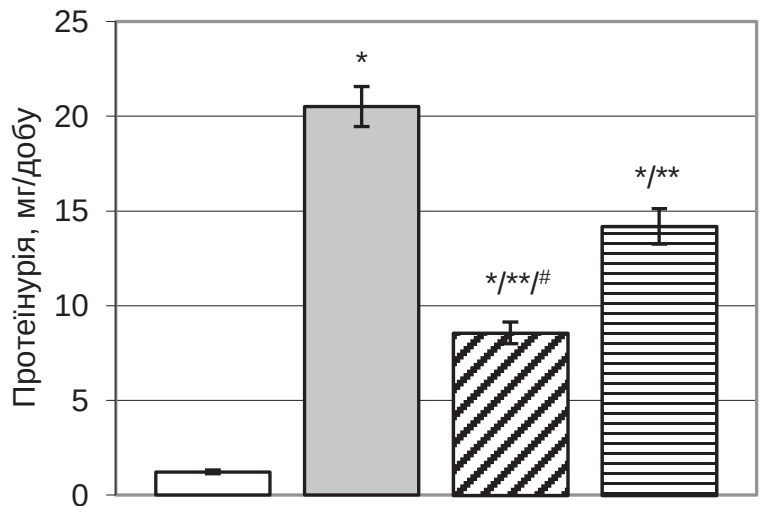

口Псевдооперований контроль

口Контрольна патологія

口НАГ/корвітин, 30 мг/кг

曰Корвітин, 34 мг/кг

Рис. 1. Вплив комбінації $\mathrm{N}$-ацетилглюкозаміну та корвітину на протеїнурію в щурів з гострою нирковою недостатністю $(M \pm m, n=38)$. 
Таблиця 2 - Показники азотистого обміну в щурів з гострою нирковою недостатністю під впливом

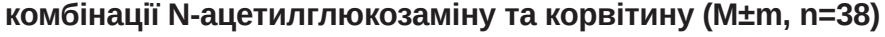

\begin{tabular}{|l|c|c|c|}
\hline \multicolumn{1}{|c|}{ Дослідна група } & $\begin{array}{c}\text { Креатинін крові, } \\
\text { мкмоль/л }\end{array}$ & $\begin{array}{c}\text { Сечовина крові, } \\
\text { ммоль/л }\end{array}$ & $\begin{array}{c}\text { Кліренс сечовини, } \\
\text { мл/добу }\end{array}$ \\
\hline Псевдооперований контроль & $57,3 \pm 1,8$ & $5,31 \pm 0,22$ & $201,5 \pm 6,2$ \\
\hline Контрольна патологія & $209,4 \pm 11,6^{\star}$ & $23,29 \pm 1,30^{\star}$ & $40,2 \pm 2,3^{*}$ \\
\hline НАГ/корвітин, 30 мг/кг & $97,1 \pm 4,9^{\star / \star \star / \#}$ & $13,71 \pm 0,45^{\star / \star \star / / *}$ & $133,2 \pm 5,0^{\star / \star \star / *}$ \\
\hline Корвітин, 34 мг/кг & $135,4 \pm 6,2^{\star / \star \star}$ & $16,82 \pm 0,65^{\star / \star \star}$ & $85,7 \pm 3,8^{\star / \star \star}$ \\
\hline
\end{tabular}
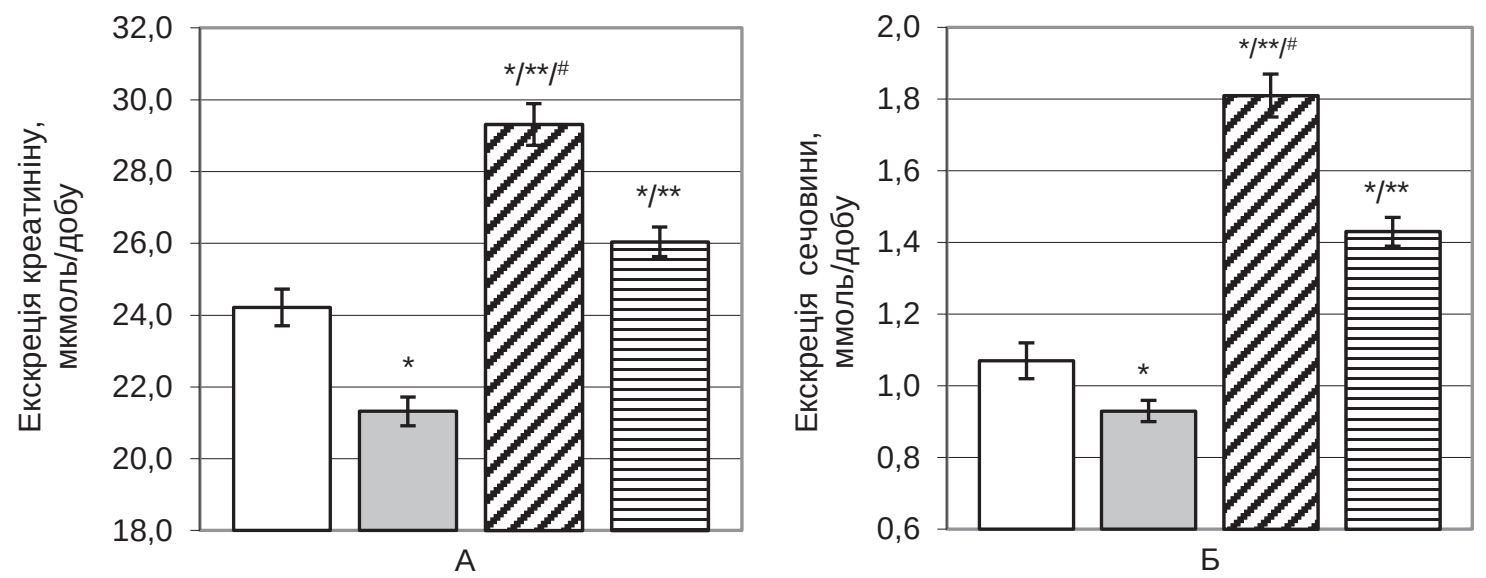

口Псевдооперований контроль 口Контрольна патологія 口НАГ/корвітин, 30 мг/кг घКорвітин, 34 мг/кг

Рис. 2. Сечова екскреція креатиніну (А) та сечовини (Б) під впливом комбінації N-ацетилглюкозаміну і корвітину в щурів 3 гострою нирковою недостатністю $(\mathrm{M} \pm \mathrm{m}, \mathrm{n}=38)$.

1,9 раза) (рис. 2). Внаслідок цього вміст креатиніну в крові вірогідно $(p<0,05)$ знижувався у 2,2 раза, а сечовини - в 1,7 раза. Також збільшувався кліренс сечовини -у 3,3 раза (табл. 2). Описана картина свідчить про покращення фрункціонального стану нирок та нормалізацію азотистого обміну в щурів з ішемічною ГНН.

Препарат порівняння "Корвітин" проявив дещо меншу ефрективність. Під його впливом рівень виживаності щурів становив $80 \%$, що не мало вірогідних розбіжностей з нелікованими тваринами (табл. 1). Діурез вірогідно $(p<0,05)$ зменшувався в 1,3 раза, показник ШКФ підвищувався в 1,9 раза, а КР - на 7,7 \% (табл. 1). Також вірогідно $(p<0,05)$ знижувалася протеїнурія - в 1,5 раза порівняно з групою контрольної патології (рис. 2).

Додатково корвітин сприяв посиленню екскреції креатиніну в 1,2 раза, а сечовини - в 1,5 раза, а також знижував їх вміст у крові в 1,6 та 1,4 раза відповідно (табл. 2). При цьому посилювалось очищення крові від сечовини, що підтверджувалося вірогідним збільшенням ії кліренсу в 2,1 раза порівняно 3 нелікованою групою (рис. 3). Усе це свідчило про покращення фрункціонального стану нирок щурів з ішемічною ГНН під впливом корвітину, але що стосується есрективності, то він вірогідно $(p<0,05)$ поступався комбінації НАГ/корвітин за всіма дослідженими показниками.
Високу ефективність комбінації можна пояснити тим, що обидва її компоненти при окремому застосуванні позитивно вливають на перебіг ниркової патології. Так, ефективність кверцетину було підтверджено в багатьох дослідженнях у різних лікарських фрормах, у тому числі при ін'єкційному використанні [4, 13-15]. Похідні глюкозаміну також проявили виражені нефрропротекторні властивості в експерименті $[5,6]$. При цьому було доведено, що він долучається до ушкоджених структур ниркової тканини і підвищує в ній вміст ендогенних гексозамінів [5]. Дані результати корелюють з іншими дослідженнями, в яких показано ефективність глюкозаміну при лікуванні фіброзу нирок у мишей [16] та контрастіндукованої ГНН у щурів [17], а також ефрективність його кон'югатів у щурів з ішемічною ГНH $[18,19]$.

Важливо також, що НАГ та кверцетин чинять несрропротекторний вплив за різними механізмами дії. N-ацетилглюкозамін є активним метаболітом ГА і проявляє пряму захисну дію, долучаючись до глікозаміногліканів і протеогліканів, які вкривають поверхню гломерулярних базальних мембран та утворюють міжклітинну речовину $[7,20]$. Його безумовна перевага - виражений посилювальний вплив на гломерулярну фільтрацію, про що свідчать результати вивчення есрективності дослідної комбінації. Разом із тим, нефропротекторна дія кверцетину реалізується 
через антиоксидантний, антигіпоксичний, протизапальний та інші ефекти [3]. Ін'єкційний спосіб введення додає переваг обом компонентам, оскільки дозволяє нівелювати вплив ефректу первинного проходження і забезпечити надходження всієї введеної дози активних речовин до системи кровообігу та ниркової тканини в незміненому вигляді.

Таким чином, отримані дані свідчать про те, що в щурів $з$ ішемічною ГНН комбінація НАГ/ корвітин в ін'єкційній лікарській формі чинить виражену нефропротекторну і гіпоазотемічну дію та є перспективним засобом для корекції ГНН, а також загострень хронічної ниркової патології. Ці результати мають вагоме значення для клінічної несрології, оскільки відкривають великі перспективи застосування нового препарату несропротекторної дії для лікування гострих уражень нирок - комбінації НАГ та кверцетину (1:1) в ін'єкційній фрормі.

\section{СПИСОК ЛІТЕРАТУРИ}

1. Lerma E. Nephrology Secrets / E. Lerma, M. Sparks, J. Topf. - 4th ed. - Philadelphia : Elsevier 2019. $-654 \mathrm{p}$.

2. Comprehensive Clinical Nephrology / J. Feehally, J. Floege, R. J. Johnson, M. Tonelli. $-6^{\text {th }}$ ed. - Philadelphia : Elsevier, 2019. - 1570 p.

3. Anand D. A. V. Overviews of biological importance of quercetin: a bioactive flavonoid / D. A. V. Anand R. Arulmoli, S. Parasuraman // Pharmacognosy Review. - 2016. - 10 (20). - P. 84-89.

4. Effects of quercetin and its combinations on health / S. K. Shebeko, I. A. Zupanets, O. S. Popov [et al.] // Polyphenols: Mechanisms of Action in Human Health and Disease. $-2^{\text {nd }} \mathrm{ed}$. - London : Academic Press, 2018. - P. 373-394.

5. Зупанец И. А. Динамика содержания эндогенного глюкозамина у лабораторных животных с несрропатией под воздействием экспериментальной терапии / И. А. Зупанец, С. К. Шебеко // Эксперим. и клинич. фармакология. - 2006. - 69, № 6. - С. 40-42.

6. Шебеко С. К. Дослідження фрармакологічних властивостей деяких похідних глюкозаміну в умовах розвитку експериментального аутоімунного гломерулонесриту / С. К. Шебеко, І. А. Зупанець // Клініч. фармація. - 2006. - 10, № 2. - С. 31-35.

7. Baynes J. W. Medical Biochemistry / J. W. Baynes, M. H. Dominiczak. - 5th ed. - Philadelphia : Elsevier, 2019. - $712 \mathrm{p}$.

8. Guide for the care and use of laboratory animals. $8^{\text {th }}$ ed. - Washington: The National Academies Press, 2011. -246 p.

9. Directive 2010/63/EU of the European Parliament and of the Council of 22 September 2010 on the protection of animals used for scientific purposes // Official Journal of the European Union. - 2010. - L276. P. 33-79.
ВИСНОВКИ. 1. При комбінуванні N-ацетилглюкозаміну і кверцетину в ін'єкційній лікарській формі у співвідношенні 1:1 значно посилюється нефропротекторна та гіпоазотемічна дія, що зумовлює виражений позитивний вплив препарату на перебіг ішемічної гострої ниркової недостатності в щурів.

2. Що стосується ефективності при гострій нирковій недостатності у тварин, то дослідна комбінація вірогідно перевершує дію препарату порівняння "Корвітин”, що є парентеральною формою кверцетину, за всіма дослідженими показниками.

3. Комбінація $\mathrm{N}$-ацетилглюкозаміну та кверцетину в ін'єкційній лікарській фрормі є перспективним засобом для корекції гострої ниркової недостатності, а також загострень хронічної ниркової патології.

10. Методи експериментального моделювання ураження нирок для фрармакологічних досліджень : метод. рек. / [С. Ю. Штриголь, В. М. Лісовий, І. А. Зупанець та ін.]. - Х. : Вид-во НФаУ, 2009. - 48 с.

11. Камышников В. С. Методы клинических лабораторных исследований / В. С. Камышников. 8-е изд. - М. : МЕДпресс-инфрорм, 2016. - 736 с.

12. Islam M. A. Foundations of Biostatistics / M. A. Islam, A. Al-Shiha. - Singapore : Springer, 2018. - 474 p.

13. Quercetin treatment improves renal function and protects the kidney in a rat model of adenine-induced chronic kidney disease / H. Yang, Y. Song, Y. N. Liang, R. Li // Med. Sci. Monit. - 2018. - 24. - P. 4760-4766.

14. The effects of quercetin on oxidative stress and fibrosis markers in chronic kidney disease rat model / K. Layal, I. S. Perdhana, M. Louisa [et al.] // Med. J. Indones. - 2017. - 26. - P. 169-77.

15. Flavonoids in kidney health and disease [Electronic resource] / F. Vargas, P. Romecín, A. I. GarcíaGuillén [et al.] // Front. Physiol. - 2018. - 9. - Article ID 394. - Access mode : https://www.ncbi.nlm.nih.gov/pmc/ articles/PMC5928447.

16. Glucosamine hydrochloride exerts a protective effect against unilateral ureteral obstruction-induced renal fibrosis by attenuating TGF- $\beta$ signaling / J. Park, S. Y. Lee, A. Ooshima [et al.] // J. Mol. Med. - 2013. - 91 (11). P. 1273-1284.

17. Augmented O-GlcNAc signaling via glucosamine attenuates oxidative stress and apoptosis following contrast-induced acute kidney injury in rats / J. Hu, R. Chen, P. Jia [et al.] // Free Radic. Biol. Med. - 2017. 103. - P. 121-132.

18. Mechanistic studies of a novel mycophenolic acid-glucosamine conjugate that attenuates renal ischemia/reperfusion injury in rat / X. Wang, M. Xiong, Y. Zeng [et al.] // Mol. Pharm. - 2014. - 11. - P. 3503-3514. 
19. Renal-targeting triptolide-glucosamine conjugate exhibits lower toxicity and superior efficacy in attenuation of ischemia/reperfusion renal injury in rats / Y. Fu, Q. Lin, T. Gong [et al.] // Acta Pharmacol. Sin. - 2016. - 37. P. 1467-1480.
20. Morita $\mathrm{H}$. The role of heparan sulfate in the glomerular basement membrane / $\mathrm{H}$. Morita, A. Yoshimura, K. Kimata // Kidney International. - 2008. - 73. - P. 247248.

\section{REFERENCES}

1. Lerma, E., Sparks, M., \& Topf, J. (2019). Nephrology Secrets (4th ed.). Philadelphia: Elsevier.

2. Feehally, J., Floege, J., Johnson, R. J., \& Tonelli, M. (2019). Comprehensive Clinical Nephrology (6th ed.). Philadelphia: Elsevier.

3. Anand, D.A.V., Arulmol, R., \& Parasuraman, S. (2016). Overviews of biological importance of quercetin: a bioactive flavonoid. Pharmacognosy Review, 10 (20), 84-89.

4. Shebeko, S.K., Zupanets, I.A., Popov, O.S., Tarasenko, O.O., \& Shalamay, A.S. (2018). Effects of Quercetin and Its Combinations on Health. Watson, R.R., Preedy, R.V., Zibadi, S. (Eds.). Polyphenols: Mechanisms of Action in Human Health and Disease (2nd ed., pp. 373-394). London: Academic Press.

5. Zupanets, I.A., \& Shebeko, S.K. (2006). Dinamika soderzhaniya endogennogo glyukozamina u laboratornykh zhivotnykh s nefropatiey pod vozdeystviyem eksperimentalnoy terapii [The influence of experimental therapy on the dynamics of endogenous glucosamine content in laboratory animals with nephropathy]. Eksperimentalnaya i klinicheskaya farmakologiya - Experimental and Clinical Pharmacology, 69 (6), 40-42 [in Russian].

6. Shebeko, S.K., \& Zupanets, I.A. (2006). Doslidzhennia farmakolohichnykh vlastyvostei deiakykh pokhidnykh hliukozaminu v umovakh rozvytku eksperymentalnoho autoimunnoho hlomerulonefrytu [Study of the pharmacological properties of some glucosamine derivatives under conditions of development of experimental autoimmune glomerulonephritis]. Klinichna farmatsiia - Clinical Pharmacy, 10 (2), 31-35 [in Ukrainian].

7. Baynes, J.W., \& Dominiczak, M.H. (2019). Medical Biochemistry (5th ed.). Philadelphia: Elsevier.

8. Guide for the care and use of laboratory animals (8th ed.). (2011). Washington: The National Academies Press.

9. Directive 2010/63/EU of the European Parliament and of the Council of 22 September 2010 on the protection of animals used for scientific purposes (2010). Official Journal of the European Union, L276, 33-79.

10. Shtryhol, S.Yu., Lisovyi, V.M., Zupanets, I.A., Shebeko, S.K., Maslova, N.F., Hozhenko, A.I., ... Harchenko, D.S. (2009). Metody eksperymentalnoho modeliuvannia urazhennia nyrok dlia farmakolohichnykh doslidzhen: metodychni rekomendatsii [Methods of experimental modeling of kidney injury for pharmacological researches: methodical recommendations]. Kharkiv: Vydavnytstvo NFaU [in Ukrainian].

11. Kamyshnikov, V.S. (2016). Metody klinicheskikh laboratornykh issledovaniy [Methods of clinical laboratory tests]. Moscow: MEDpress-inform [in Russian].

12. Islam, M.A., \& Al-Shiha, A. (2018). Foundations of Biostatistics. Singapore: Springer.

13. Yang, H., Song, Y., Liang, Y.N., \& Li, R. (2018). Quercetin treatment improves renal function and protects the kidney in a rat model of adenine-induced chronic kidney disease. Med. Sci. Monit., 24, 4760-4766.

14. Layal, K., Perdhana, I.S., Louisa, M., Estuningtyas, A., \& Soetikno, V. (2017). The effects of quercetin on oxidative stress and fibrosis markers in chronic kidney disease rat model. Med. J. Indones., 26, 169-177.

15. Vargas, F., Romecín, P., García-Guillén, A.I., Wangesteen, R., Vargas-Tendero, P., Paredes, M.D., ... García-Estañ, J. (2018). Flavonoids in kidney health and disease. Front. Physiol., 9, 394.

16. Park, J., Lee, S.Y., Ooshima, A., Yang, K.M., Kang, J.M., Kim, Y.W., \& Kim, S.J. (2013). Glucosamine hydrochloride exerts a protective effect against unilateral ureteral obstruction-induced renal fibrosis by attenuating TGF- $\beta$ signaling. Journal of Molecular Medicine, 91 (11), 1273-1284.

17. Hu, J., Chen, R., Jia, P., Fang, Y., Liu, T., Song, N., ... Ding, X. (2017). Augmented O-GlcNAc signaling via glucosamine attenuates oxidative stress and apoptosis following contrast-induced acute kidney injury in rats. Free Radic. Biol. Med., 103, 121-132.

18. Wang, X., Xiong, M., Zeng, Y., Sun, X., Gong, T., Zhang, Z. (2014). Mechanistic studies of a novel mycophenolic acid-glucosamine conjugate that attenuates renal ischemia/reperfusion injury in rat. Mol. Pharm., 11, 3503-3514

19. Fu, Y., Lin, Q., Gong, T., Sun, X., \& Zhang, Z.R. (2016). Renal-targeting triptolide-glucosamine conjugate exhibits lower toxicity and superior efficacy in attenuation of ischemia/reperfusion renal injury in rats. Acta Pharmacol. Sin., 37 (11), 1467-1480.

20. Morita, H., Yoshimura, A., Kimata, K. (2008). The role of heparan sulfate in the glomerular basement membrane. Kidney International, 73, 247-248. 


\title{
ВЛИЯНИЕ КОМБИНАЦИИ N-АЦЕТИЛГЛЮКОЗАМИНА И КВЕРЦЕТИНА В ИНЪЕКЦИОННОЙ ФОРМЕ НА ТЕЧЕНИЕ ИШЕМИЧЕСКОЙ ОСТРОЙ ПОЧЕЧНОЙ НЕДОСТАТОЧНОСТИ У КРЫС
}

\begin{abstract}
Резюме
Вступление. Оптимизация лечения острой почечной недостаточности (ОПН) - важная медико-срармацевтическая проблема. Острая почечная недостаточность является распространенным осложнением не только заболеваний почек, но и различных паллиативных и оперативных методов лечения. В отдельных группах больных смертность от нее достигает 80 \%. Поэтому поиск эффрективных средств коррекции ОПН является актуальной задачей современной экспериментальной фрармакологии. Перспективным подходом в решении данной проблемы может стать внедрение фрармацевтической комбинации на основе фрлавоноида кверцетина и аминосахара $N$-ацетилглюкозамина в инъекционной фрорме.

Цель исследования - провести экспериментальное изучение эфорективности комбинации $\mathrm{N}$-ацетилглюкозамина и кверцетина в инъекционной фрорме в условиях развития ишемической острой почечной недостаточности.

Методы исследования. Исследования выполняли на модели ишемической ОПН у крыс, которую воспроизводили путем тотальной окклюзии почечных сосудов в течение 75 мин. Исследуемую комбинацию изучали в дозе 30 мг/кг при ежедневном внутривенном введении в течение 3-х суток в сравнении с кверцетином (препарат “Корвитин”), который вводили внутривенно в дозе 34 мг/ка. Эфрфективность препаратов оценивали по общему фризическому состоянию животных, выделительной фрункции почек и показателям азотистого обмена.

Результаты и обсуждение. Под влиянием исследуемой комбинации у крыс с ОПН достоверно $(p<0,05)$ относительно нелеченных животных снижалась летальность, наблюдали уменьшение диуреза в 1,5 раза, протеинурии в 2,4 раза, усиление клубочковой фрильтрации в 3,0 раза и канальцевой реабсорбции на 9,9 \%, повышение мочевой экскреции креатинина в 1,4 раза и мочевины в 1,9 раза, что в челом свидельствовало о нормализации функционального состояния почек и азотистого обмена. Что касается эфрфективности, то комбинация при этом достоверно $(p<0,05)$ превосходила действие корвитина по всем исследованным показателям.

Выводы. Комбинация N-ацетилглюкозамина и кверцетина - эффрективное средство коррекции острой почечной недостаточности, которое можно вводить внутривенно. Целесообразно дальнейшее изучение этого препарата как средства лечения почечной патологии.
\end{abstract}

КЛЮЧЕВЫЕ СЛОВА: N-ацетилглюкозамин; кверцетин; инъекционная фрорма; острая почечная недостаточность.

S. K. Shebeko, I. A. Zupanets, T. S. Sakharova NATIONAL UNIVERSITY OF PHARMACY, KHARKIV

\section{INFLUENCE OF THE N-ACETYLGLUCOSAMINE AND QUERCETIN COMBINATION IN THE INJECTABLE DOSAGE FORM ON THE COURSE OF ISCHEMIC ACUTE KIDNEY INJURY IN RATS}

\section{Summary}

Introduction. Optimization of the treatment of acute kidney injury (AKI) is an important medical and pharmaceutical problem. AKI is a common complication not only of kidney diseases, but also of various treatment methods. Mortality caused by AKI reaches $80 \%$ in some groups of patients. Therefore, the search for effective agents for AKI treatment is an important task of modern experimental pharmacology. A promising approach in the solution of this problem may be the implementation of pharmaceutical combination of flavonoid quercetin and amino sugar $\mathrm{N}$-acetylglucosamine in injectable dosage form.

The aim of the study - experimental study of the efficacy of $\mathrm{N}$-acetylglucosamine and quercetin combination in injectable dosage form under the condition of ischemic AKI.

Research Methods. Studies were performed on a model of ischemic AKI in rats, which was induced by total occlusion of the renal blood vessels for 75 minutes. The test combination was studied at a dose of $30 \mathrm{mg} / \mathrm{kg}$ with 
daily intravenous (i.v.) administration for 3 days in comparison with quercetin ("Corvitin" medication), which was injected i.v. at a dose of $34 \mathrm{mg} / \mathrm{kg}$. The efficacy of test drugs was assessed by the animal functional state, excretory renal function and nitrogen metabolism indicators.

Results and Discussion. Under the influence of test combination, there was a significant decrease $(p<0.05)$ in mortality rate in rats with AKI compared to untreated animals, a decrease in diuresis by 1.5 times and proteinuria by 2.4 times, an increase in glomerular filtration by 3.0 times and tubular reabsorption by $9.9 \%$, creatinine and urea excretion were increased by 1.4 and 1.9 times, respectively, which indicates the normalization of kidney functional state and nitrogen metabolism. Moreover, the combination was significantly $(p<0.05)$ superior to the Corvitin effect in efficacy level by all studied parameters.

Conclusions. Thus, the $\mathrm{N}$-acetylglucosamine and quercetin combination is an effective agent for AKI treatment, which can be used at i.v. administration. It is advisable to further study of this drug as a therapy for renal pathology.

KEY WORDS: N-acetylglucosamine; quercetin; injectable dosage form; acute kidney injury.

Отримано 18.07.19

Адреса для листування: С. К. Шебеко, Національний фрармацевтичний університет, вул. Пушкінська, 27, Харків, 61057, Україна, e-mail: shebeko.sk@gmail.com. 